In 1732, for example, both Maskelyne and Lalande were born. For forty-six years Maskelyne (17321811) was Astronomer Royal, and to him was due the founding of the Nautical Almanac. Lalande (1732-1807) also has many claims to our homage. Indefatigable in his exertions on behalf of science, by his lectures at the Collége de France he gained for astronomy an unexampled popularity, and one of his books was called "the great newspaper of astronomy". It was to Maskelyne that Herschel first communicated the discovery of the heavenly body now known as the planet Uranus, but it was Lalande who wished to call it Herschel, a name it was actually known by for some years. Another astronomer born in 1732 was David Rittenhouse (1732-96), who succeeded Franklin as president of the Philosophical Society of Philadelphia and was among the first to welcome Priestley to America. The French mineralogist, Gabriel Jars (1732-69), the compiler of the "Voyages métallurgiques"; Alexander Cronstedt (1732-65), the Swedish discoverer of nickel, were also born the same year, as also was Richard Arkwright (1732-92), the greatest of the founders of our textile industry.
Carrying the survey a hundred years still further back, in 1632 Sir Christopher Wren and the great Dutch naturalist Leeuwenhoeck were both born, while that year saw the deaths of several mathematicians who were contemporaries of Kepler, Napier, and Galileo. The two British mathematicians, Thomas Allen (1542-1632) and Nathaniel Torporley (1564-1632), died in September and April respectively; the Dutch mathematician, Albert Girard (1595-1632), who collected and published the works of Stevinus and discovered various properties of spherical triangles, died in December ; Lansberg (1561-1632), of Belgium, both mathematician and astronomer, whose tables were used by Horrocks, died in. November ; Christopher Borrus (1583-1632), of the Society of Jesus, who travelled to the Far East and in his charts of the Atlantic and Indian Ocean anticipated some of the work of Halley, died at Rome in May 1632, while another mathematician who died that year was Jobst Bürgi (1552-1632), whose system of anti-logarithms was worked out by him independently of the contemporary discoveries of Napier.

\title{
Hydro-Electric Power Development in the Pyrenees.
}

By Dr. Brysson Cunningham.

$A^{N}$ interesting and efficient system of electric A power generation and distribution, serving the Southern Railway of France (Chemins de Fer du Midi) and a number of important regional industries, has been developed, mainly during the past decade, from the natural water resources of the western Pyrenees. During a recent tour in southern France, I was afforded, through the courtesy of the Midi Company, an opportunity of visiting several of the generating stations, and the following is a bpief description of the salient features of the undertaking, known as the Union des Producteurs d'Électricité des Pyrénées Occidentales (U.P.E.P.O), which controls more than half a million horse-power, say onefourth of the total water power developed in France, as registered at the end of 1930. The gross potential water resources of that country are estimated to be between nine and ten million horse-power.

The Pyrenees, forming, as is well known, the frontier barrier between France and Spain, with a length of about 240 miles between Cape Cerbera on the Mediterranean littoral and the south-eastern corner of the Bay of Biscay, apart from their engaging geological structure, present an interesting hydrographic feature, in that there is a marked difference in the rainfall and snowfall between the eastern and western halves of the chain, the quan- tity being much greater in the west. I certainly acquired a confirmatory impression of the western abundance during three consecutive days spent in the neighbourhood of $\mathrm{Pau}$ in September, when the rainfall was almost incessant and its intensity surprising. The notable absence of glaciers in the

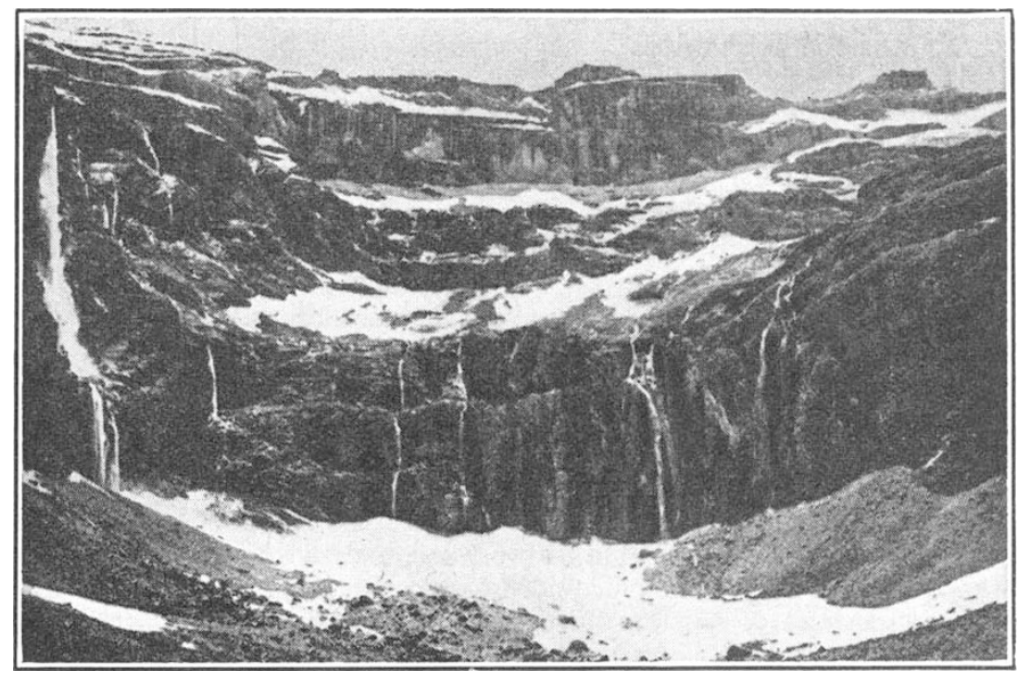

FIG. 1.-Cirque de Gavarnie.

eastern Pyrenees is accounted for by the insufficiency of the falls of snow for their formation. Ob. viously then, the great preponderance of moisture in the centre and west has marked out this region as a suitable area of exploitation for the development of hydro-electric power, and it is within the limits of the latitude of Oloron in the west and the

No. 3244, VoL. 129] 
Val d'Aran in the east that the leading stations of the U.P.E.P.O. are located.

From the hydrographic point of view, several other characteristic features of the range lend themselves admirably to water-power development. Despite the general absence of great lakes, such as those in the Alps, there is a number of natural

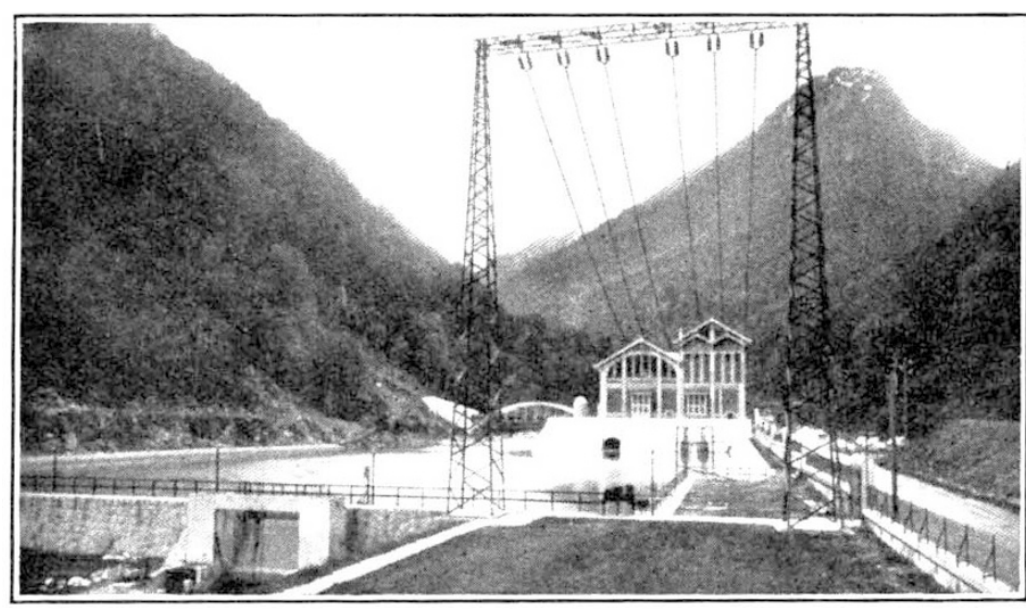

FIG. 2.-Miègebat generating station. The pipe lines are to the left and cannot be seen in the photograph. They enter the station across the bridge in the background.

basins of moderate extent, which have been adapted as storage reservoirs for a working or a reserve supply of water, possessing potential energy of high value. In addition, waterfalls are numerous and lofty, being surpassed in Europe only by those of Scandinavia. The highest is the celebrated Cascade de Gavarnie with a fall of $1515 \mathrm{ft}$. The mountain streams or torrents which give rise to these falls are known locally as "gaves

It is a curious feature of the topography of the Pyrenees that the upper ends of the valleys frequently expand into gigantic arcs of circles surrounded by towering, precipitous cliffs, crowned by snow and ice. These enlargements are designated 'cirques'. The most notable is the Cirque de Gavarnie at a height of $5000 \mathrm{ft}$. above sealevel, about a mile and a quarter in diameter, with rugged sides several thousand feet high, scored and intersected by hundreds of silvery cascades, including the Cascade de Gavarnie mentioned above (Fig. 1).

The U.P.E.P.O. came into existence in the early part of 1923 , with the object of utilising to the best advantage the supplies of hydro-electric power in the western Pyrenees, by providing service lines to distant centres of consumption and by regulating the output of the various generating stations, using the surplus, after meeting the requirements of railway traction, for chemical and metallurgical industries. Eleven bodies are now affiliated to the Union, which possesses thirty 'centrales' or generating stations, totalling a maximum available power of $400,000 \mathrm{kva}$. and producing energy in a normal year to the extent of more than 1500 millions of kilowatt-hours.

Of the thirty stations, the Midi Railway Company operates five of the largest: three in a chain, or stepped series, and two detached and isolated insulations. The chain lies in the upper valley of Ossau and commences at summit level with a source in the lake Artouste, a deep basin situated near the frontier line with its natural surface at a height of 1968.6 metres above sea-level. By means of a dam, the depth of water has been increased by 25 metres so as to form a reservoir with a capacity of 25 million cubic metres. From the lake a tunnel through the granite rock, $8.5 \mathrm{~km}$. in length and about $6 \mathrm{ft}$. in diameter, conducts the water to a point just above the station of Artouste, which is entered by means of three pressure tubes under a gross head of 758 metres. The diameter of the tubes gradually decreases from $800 \mathrm{~mm}$. to $600 \mathrm{~mm}$. The flow actuates three Pelton wheels, each of 10,000 horse-power, coupled to three C.E.F. alternators of $7000 \mathrm{kw}$. capacity.

Aftex passing through the Artouste Station, the water is received into two basins, each of 95,000 metres capacity, in succession, forming a working reservoir for the next station below at Miègebat, distant about 7.6 kilometres (Fig. 2). These basins also receive direct the waters of two mountain streams, or gaves: the Gave de Bious and the Gave de Brousset. The combined supply enters the Miège-

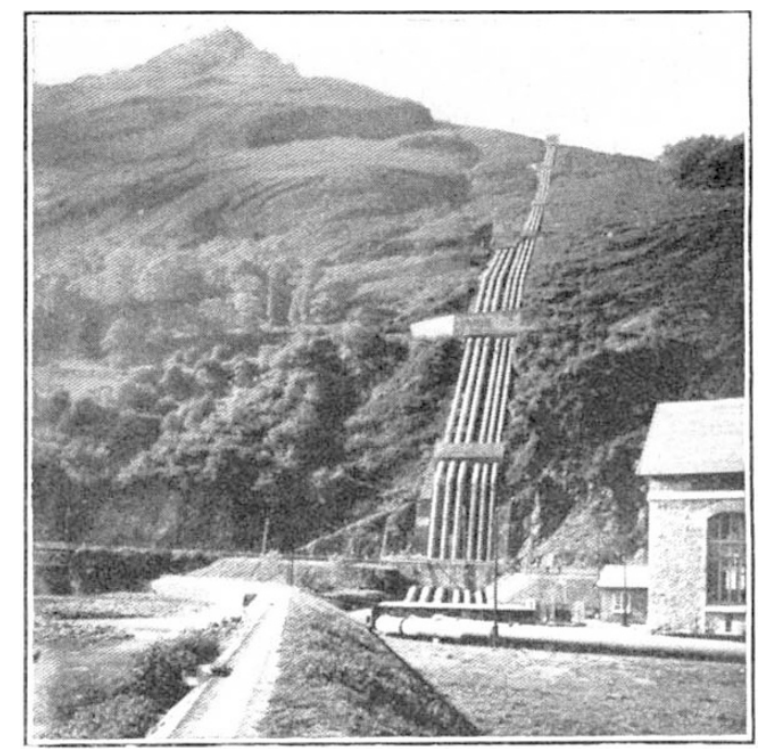

Fra. 3.-Soulom generating station and pipe lines.

bat Station through four pressure tubes of 950 $\mathrm{mm}$. diameter, under a net head of 380 metres. The generating plant consists of five Pelton turbines of 10,000 horse-power each and five alternators of 7000 kilowatts.

The next and final stage is the drop to the level of the station of Le Hourat, which is adjacent to

No. 3244, VoL. 129] 
the head of the railway line at Laruns. The water is conducted through a canal having a length of 5.75 kilometres to four pressure tubes of $1200 \mathrm{~mm}$. diameter, falling through which under a head of 204 metres, it actuates five Francis turbo-alternators of 10,000 horse-power each. Altogether, throughout the entire length of the Ossau Valley, there is plant for the development of 130,000 horsepower, producing 230 millions of $\mathrm{kwh}$. annually.

The detached stations are those of Soulom and Eget. The former (Fig. 3) adjoins the railway line at Pierrefitte and is not far distant from the charming mountain resort of Cauterets, which is reached by an electrically operated tramway. The station at Soulom receives supplies of water from the Gave de Pau and the Gave de Cauterets under very different heads-the former being low and the latter high-necessitating two distinct forms of generation. The net fall of the Gave de Cauterets is 240 metres, and the water is conveyed through three pressure tubes of $810 \mathrm{~mm}$. diameter to two Pelton wheels of 3500 horse-power, each coupled to alternators. The fall of the Gave de Pau is only 106 metres, and in this case the three pressure tubes have a diameter of $1200 \mathrm{~mm}$. and the generating plant consists of three Francis turbines of 3500 horse-power each. The total capacity of the station, accordingly, is 21,000 horse-power, and its annual output is 80 million $\mathrm{kwh}$. It is the smallest of the Midi installations, and was inaugurated before the War. A curious feature which I noticed is the variegated colouring of the pressure tubes, which, at first glance, I thought might possibly be a relic of War-time camouflage, especially as it had a faded appearance. I was told, however, that it was an attempt at rsthetic treatment with the view of harmonising the appearance of the pipes with the mountain background. As such, it could not be considered altogether successful. If a pipe line can be hidden or rendered less obtrusive by shrubs and vegetation, the advantage from a scenic point of view is, no doubt, considerable, but variegated tinting of the pipes only seems to produce a tawdry and unquestionably artificial effect.

The last station to be noticed is that of Eget (Fig. 4), which is located in the high valley of $\mathrm{La}$ Neste de Couplan. It benefits in part from an arrangement made in 1870 by the French Minister of Agriculture in order to create dry weather reserves to feed the lakes of the region, the streams of the plateau of Lannemezan, and the district of Gers. The following four lakes have accordingly been impounded so as to provide increased capacities, namely:

$\begin{array}{ll}\text { Orédon } & 7,000,000 \mathrm{cu} . \mathrm{m} . \\ \text { Cap de Long } & 7,000,000 ", \\ \text { Aumar } & 1,100,000 ", \\ \text { Aubert } & 4,500,000, "\end{array}$

In addition, the Midi Company, by means of a barrage, has formed in the valley of the Oule an artificial reservoir of $6,500,000$ cu.m. capacity, receiving supplies from a catchment area of 30 square kilometres. This brings the available reserves for the Eget Station up to 25 million cu.m.
The head at the station is 710 metres, and the water passes through seven tubes of $560 \mathrm{~mm}$. diameter to a corresponding number of turbo-alternators of 5000 horse-power each. The mean annual output is 90 million $\mathrm{kwh}$., of which 30 millions, due to stream flow, must be consumed between the months of April and July, while the remainder, provided by lake supply, ean be consumed as required.

Time did not permit me to visit any stations outside the Midi groups. With three exceptions,

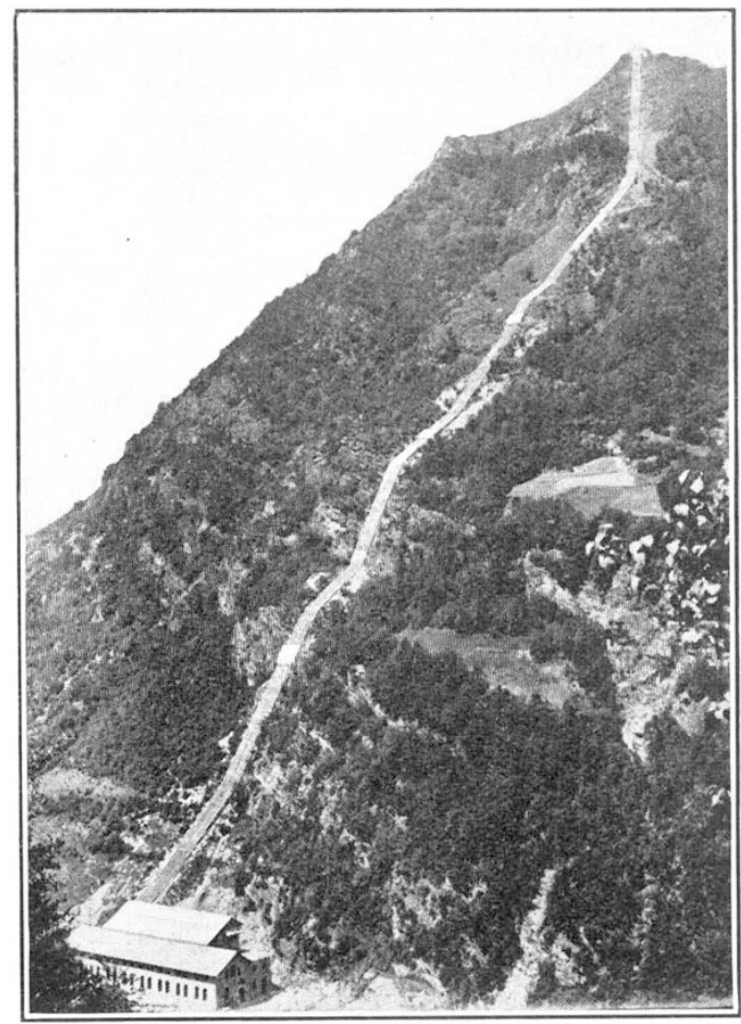

FIG. 4.-Eget generating station and pipe lines.

however, the rest are of relatively minor calibre, that is, less than an aggregate of 20,000 horse-power per station. The largest is one of 50,000 horsepower at Pinet, operated by the Énergie Électrique du Rouergue. Two others, of 35,000 and 33,000 horse-power respectively, belong to the Societé Hydroéletrique de la Cère and the Sté. des Forces Électriques de la Vallée de Gavarnie.

An account of the stations can scarcely be considered complete without some reference to the system of distribution, which is very capably organised and constitutes one of the chief duties and responsibilities of the Union. The U.P.E.P.O. takes delivery of the energy furnished by its affiliated concerns at a tension of 60,000 volts at one or other of two transformer stations at Lannemezan or Laruns, belonging to the Midi Company, where, apart from a quota to meet local demands, it is transformed to a voltage of 150,000 and dispatched in the directions of Bordeaux and Toulouse. Each concern undertakes the transport of its. own output to the points of delivery. Two lines of A 2

No. 3244, VoL. 129] 
$50,000 \mathrm{kw}$. convey the current to Bordeaux and one of $50,000 \mathrm{kw}$. to Toulouse and beyond, the total distance exceeding 500 kilometres. At the two extremities of the high-tension system (Bordeaux and Toulouse) and at the intermediate point of Dax there are transformer stations to reduce the voltage again to 60,000 . The various demands of traction and industry are met from these centres, as well as from those of Laruns and Lannemezan.

The duties of the central organisation of the U.P.E.P.O. at Tarbes are considerable. Each day it is furnished by its constituent units with detailed particulars of the previous day's output, the energy available, the local requirements, the state of the water supply, lake levels, etc. From these data is prepared a chart of the aggregate resources, and a scheme of apportionment is arranged to meet the fluctuating demand, the deficiency at one centre being made good by the surplus at another. The whole system is planned, in fact, with the view of eliminating unnecessary waste, obviating local breakdowns or shortage, and ensuring a regular and sufficient supply for the needs of the important region which it serves.

My acknowledgments are due to the U.P.E.P.O., as well as to the Midi Railway Company, for information courteously placed at my disposal and for their kind assistance. The photographs of the stations have been supplied by the Midi Railway Company, from which I learn that, up to the date of writing, a length of 1256 kilometres (say 785 miles) of track is electrically operated, representing about thirty per cent of the whole system. A further 336 kilometres is now being equipped for electric traction, and the electrification of a length of 270 kilometres is under consideration.

\section{Obituary.}

Dr. J. P. Lotsy.

r THE death of Dr. Johannes Paulus Lotsy, which occurred at Leyden in November at sixty-four years of age, terminates the career of one of the leading workers of the day on evolution and heredity.

Dr. Lotsy's botanical work began when he was sent out to the East Indies in 1896 to study the alkaloids contained in various species of Cinchona. The results of his work were published in 1898 . He then settled down to a long career of teaching and research in Leyden, varied by frequent visits to almost every part of the globe. In 1906 he published the first part of his "Vorlesungen über Deszendenztheorien", the second part of which appeared two years later. This very useful work was based on his lectures on evolution at Leyden and comprised a comprehensive survey of the state of evolutionary thought at the time. At the same time another monumental work began to appear, "Vorträge über botanische Stammesgeschichte", (3 vols., 1907-1911), an unfinished treatise on the plant kingdom from a phylogenetic point of view.

Lotsy now began to develop the views on evolution and the species question with which his name will always be associated. During the years 1912 to 1916 he published a series of papers putting forward the view that the fundamental unit of taxonomy was the homozygous biotype, and that to this only should be given the name species. Subsequent work has shown that such a unit has no existence in ordinary allogamous populations, and later on Lotsy himself abandoned his opinion and went to the further extreme of doubting the existence of such homozygous biotypes in Nature even in pure lines.

In 1916 Lotsy published his well-known book, "Evolution by means of Hybridisation", in which he vigorously attacked de Vries's work on mutations in Enothera, and claimed that the phenomena observed in that genus were due to the heterozygosity of the material. He advanced the view that the sole method of evolution was by means of hybridisa- tion, and denied that gene mutations played any part. The book was written in a style entirely the author's own, and many of his views cannot now be maintained, but, nevertheless, it will remain a classic in evolutionary literature. Lately, moreover, evidence has accumulated showing that hybridisation plays a greater part in evolution than Lotsy's critics imagined. One of the most striking examples of this is the grass Spartina Townsendit, which has recently been shown, beyond doubt, to have originated from a cross between $S$. alterniflora and $S$. stricta, followed by a doubling of the chromosomes. Other cases could be quoted, and it seems clear that one of the means of evolution of new species is interspecific hybridisation followed by chromosome doubling.

During the last six years, having given up regular teaching on being made emeritus professor at Leyden, Lotsy visited New Zealand, South Africa, and other parts of the world for the purpose of collecting evidence for his views on evolution. $\mathrm{He}$ was a tireless worker in the field, and everywhere he went he amassed a wealth of material and brought together a great number of arguments in support of his views. In South Africa he worked especially on the genera Cotyledon and Euphorbia, and took back material of the former genus to Leyden, where he was breeding them on a large scale. He also turned his attention to hybrid populations in the human species, and a large part of the paper on his South African work, published in conjunction with Dr. Goddijn, deals with the various races he had studied there.

At the time of his death, Lotsy was engaged on a large work dealing with his ideas on evolution, and it is much to be regretted that he did not live to bring it to completion.

Lotsy was always a welcome visitor to Great Britain, his last visit being to attend the London meeting of the British Association. His views, always frank and forcibly expressed, were very stimulating and were generally appreciated ; since,

No. 3244, VoL. 129] 